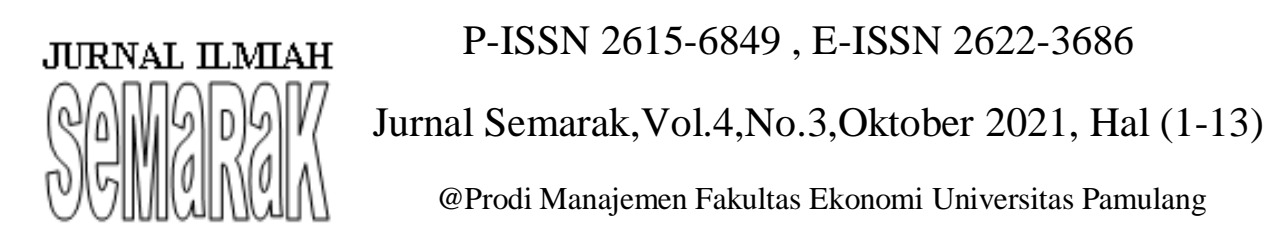

\title{
PENGARUH KOMPENSASI DAN LINGKUNGAN KERJA TERHADAP KINERJA PEGAWAI
}

\author{
Ahmad Syukri \\ Krisnaldy \\ Veta Lidya Delimah Pasaribu
}

Assiten Ahli Dan Lektor Fakultas Ekonomi Universitas Pamulang

Email: dosen01772@unpam.ac.id, dosen01890@unpam@ac.id, veta01889@unpam.ac.id

\begin{abstract}
ABSTRAK
Penelitian ini memiliki tujuan untuk mengetahui pengaruh antara kompensasi, Lingkungan Kerja terhadap kinerja pegawai di, Tangerang Selatan, untuk mengetahui pengaruh secara parsial antara kompensasi terhadap kepuasan kerja di Tangerang Selatan dan untuk mengetahui pengaruh secara simultan antara kompensasi dan lingkungan kerja terhadap kinerja pegwai di Tangerang Selatan. Data yang digunakan dalam penelitian ini menggunakan data primer yang diperoleh dari jawaban dari responden yang menjadi pegawai di Tangerang Selatan yang diberikan kuesioner. Pemilihan sampel dilakukan dengan menggunakan rumus slovin. Hasil penelitian ini menunjukkan bahwa terdapat pengaruh secara simultan pada variabel kompensasai, lingkungan kerja terhadap kinerja pegawai. Hasil penelitian ini juga menunjukkan variabel kompensasi, lingkungan kerja berpengaruh signifikan secara parsial terhadap kinerja pegawai. Pada koefisien determinasi terdapat pengaruh yang mempengaruhi kinerja pegawai yang dijelaskan oleh kompensasi dan lingkungan kerja, dan , sedangkan sisanya dipengaruhi oleh variabel lain dan tidak termasuk kedalam analisis regresi ini.
\end{abstract}

\section{Kata kunci: Kompensasi, Lingkungan Kerja, Kinerja , Pegawai}

\begin{abstract}
This study aims to determine the effect of compensation, work environment on employee performance in South Tangerang, to determine the partial effect of compensation on job satisfaction in South Tangerang and to determine the effect simultaneously between compensation and work environment on employee performance. in South Tangerang. The data used in this study uses primary data obtained from the answers of respondents who are employees in South Tangerang who were given a questionnaire. Sample selection is done using the Slovin formula. The results of this study indicate that there is a simultaneous influence on the compensation variable, work environment on employee performance. The results of this study also show that the compensation variable, the work environment partially has a significant effect on employee performance. In the coefficient of determination there is an influence that affects employee performance which is explained by compensation and work environment, and, while the rest is influenced by other variables and is not included in this regression analysis.
\end{abstract}

Keywords: Compensation, Work Environment, Performance, Employees 


\section{PENDAHULUAN}

\section{A. Latar Belakang}

Dalam sebuah perusahaan atau organisasi Pegawai merupakan aset yang sangat penting karena tanpa adanya Pegawai perusahaan atau organisasi akan sulit untuk mencapai tujuannya. Kemampuan dari seorang individu dalam melakukan pekerjaannya tergantung dari apa yang telah mereka kerjakan dan mereka dapatkan. Untuk mendapatkan hasil yang terbaik tentunya juga diperlukan adanya sumber daya manusia yang berkualitas.

Banyak faktor yang mempengaruhi keberhasilan suatu organisasi. Salah satunya adalah Pegawai, karena berkaitan langsung dengan kegiatan organisasi. Dalam hal ini Pegawai diharapkan dapat memberikan hasil yang maksimal sehingga tujuan dari perusahaan atau organisasi dapat tercapai. Untuk dapat survive perusahaan atau organisasi harus mempunyai Pegawai yang memiliki sikap yang baik dan semangat kerja yang tinggi sehingga ada rasa kepuasan dan loyalitas terhadap perusahaan.

Menurut Handoko (2014:155) masalah kompensasi merupakan fungsi manajemen personalia yang paling sulit dan membingungkan. Tidak hanya karena pemberian kompensasi merupakan salah satu tugas yang paling kompleks, tetapi juga salah satu yang paling berarti bagi Pegawai maupun organisasi.

Apabila kompensasi yang diberikan perusahaan tidak tepat, perusaha ${ }_{1}{ }^{\cdots}$;a kehilangan Pegawai yang memiliki ja baik, dan perusahaan harus mengeıuarkan biaya lagi untuk penarikan Pegawai baru atau yang biasa kita sebut dengan istilah recruitment. Akan ada dua kemungkinan yang muncul dari recruitment ini. Pertama, perusahaan berhasil mendapatkan Pegawai yang berkompeten, kedua perusahaan justru gagal untuk mendapatkan Pegawai yang berkompeten seperti yang diharapkan. Jika kemungkinan kedua yang muncul, maka sudah dipastikan perusahaan akan mengalami kerugian karena tidak dapat berkompetisi di bidang SDM (Sumber Daya Manusia) dengan kompetitor. Sebaliknya, jika program kompensasi dirasa cukup adil dan kompetitif, maka perusahaan akan lebih mudah mendapatkan kayawan yang potensial.

Kompensasi menurut Hasibuan (2012:34) adalah semua pendapatan yang berbentuk uang, barang langsung atau tidak langsung yang diterima Pegawai sebagai imbalan atas jasa yang diberikan kepada perusahaan. Tujuan pemberian kompensasi antara lain adalah sebagai ikatan kerjasama, kepuasan kerja, pengadaan efektif, motivasi, stabilitas Pegawai, disiplin, serta pengaruh serikat buruh dan pemerintah.

Kurang puasnya Pegawai dengan kompensasi yang diterima terlihat dari hasil wawancara dengan dengan 15 Pegawai Kelurahan Pondok Benda Pamulang, dari hasil wawancara diketahui jika Pegawai belum puas dengan kompensasi yang ada, hal ini berkaitan dengan bonus, tunjangan serta insentif yang didapat. Para Pegawai merasa gaji yang diterima belum adil karena beban kerja yang diterima tidak sebanding dengan kompensasi yang didapat.

Selain faktor kompensasi, lingkungan kerja juga dapat mempengaruhi kinerja Pegawai, semakin banyak tekanan didalam ruangan kerja serta tidak adanya ruangan yang kondusif sangat berpengaruh terhadap prestas kerja Pegawai. Perusahaan harus lebil mempertimbangkan hal-hal seperti ini aga lebih memudahkan Pegawai untuk bekerj: serta untuk mencapai tujuan perusahaan.

Tekanan di dalam lingkungan kerja juga dapat mengganggu psikologis Pegawai, dengan adanya suasana yang cukup memadai untuk Pegawai, maka semakin banyak produktifitas yang dihasilkan, dan peningkatan jumlah Pegawai yang bekerja di perusahaan akan 
semakin meningkat. Lingkungan kerja yang baik, tata ruang serta suasana yang memadai akan mendukung pelaksanaan kerja Pegawai, maka Pegawai akan mudah termotivasi. Contohnya dengan menyediakan tata ruang yang menyenangkan, serta penerangan yang baik maupun alunan musik yang merdu.

Terdapat pula masalah lingkungan kerja yang ada di Kelurahan Pondok Benda Pamulang. Lingkungan kerja menjadi komponen utama dimana pertama kali kontak dengan dunia kerja dilakukan oleh seorang Pegawai. Kenyamanan dalam bekerja seorang Pegawai ditentukan oleh lingkungan kerja di sekitarnya. Semakin baik dan kondusif lingkungan kerja Pegawai, kenyamanan kerja yang didapatkan pun akan semakin besar.

Lingkungan kerja adalah sesuatu yang ada disekitar para pekerja dan yang mempengaruhi dirinya dalam menjalankan tugas-tugas yang dibebankan, hal ini berarti lingkungan kerja yang kondusif dan sesuai akan sangat berpengaruh terhadap kinerja Pegawai. Baik buruknya kinerja pegawai dipengaruhi sedikit banyak oleh lingkungan kerja yang ada, semakin baik lingkungan yang ada semakin baik pula kinerja Pegawai, begitu juga sebaliknya.

Berdasarkan hasil wawancara pada bulan september 2019 ditemukan bahwa turunnya kinerja Pegawai disebabkan salah satunya oleh faktor lingkungan kerja, Dari hasil wawancara dengan Kepala Sub Bagian SDM didapatkan informasi bahwa di beberapa lokasi Kelurahan Pondok Benda Pamulang mengalami kebocoran ketika hujan turun.

Dari hasil observasi juga didapati kondisi tempat kerja di kantor Kelurahan Pondok Benda Pamulang masih berupa bangunan lama yang memiliki ruangan sempit. Desain tempat kerja dan bagian ruang masing-masing belum direnovasi. Kondisi ruangan yang pengap dan minim udara semakin menghambat dan mempengaruhi kinerja para Pegawai Kelurahan Pondok Benda Pamulang. Kondisi ini menyebabkan suasana kerja menjadi terganggu karena kurangnya kenyamanan yang didapatkan karyawaan dalam bekerja. Kondisi tersebut megindikasikan suasana kerja seperti indikator yang dikemukakan oleh Nitisemito (2012).

Kinerja merupakan bentuk perwujudan kerja yang optimal terhadap suatu perusahaan yang dilakukan oleh Pegawai untuk menunjukkan suatu prestasi kerjanya, biasanya juga kinerja sangat erat hubungannya dengan masalah penilaian kinerja itu sendiri. Pegawai atau pegawai di suatu organisasi atau perusahaan merupakan unsur yang penting karena Pegawai atau pegawai sangat menentukan maju atau tidaknya perusahaan tersebut. Di dalam dunia bisnis, perusahaan sangat dituntut untuk menciptakan kinerja Pegawai yang tinggi demi kemajuan perusahaan. Kinerja Pegawai yang tinggi merupakan salah satu syarat dalam pencapaian visi dan misi perusahaan. Pencapaian visi dan misi tersebut tidak lain adalah dari mengelola sumber daya manusia yang berpotensi agar dapat meningkatkan hasil kinerjanya. Selain itu, dalam mengembangkan perusahaan dunia bisnis, saat ini dituntut untuk menerapkan manajemen sumber daya manusia yang baik dan menghasilkan Pegawai yang berkualitas tinggi.

Namun dalam upaya menciptakan kinerja Pegawai yang tinggi dan optimal, nampaknya masih terdapat berbagai masalah atau kendala yang membuat perusahaan sulit untuk mencapai tujuan dari perusahaan itu sendiri. Kendala yang timbul biasanya berasal dari dalam perusahaan itu sendiri dan berkaitan dengan Pegawai. Masalah kinerja Pegawai harus diatasi dengan baik karena baik buruk kinerja Pegawai erat kaitannya dengan prestasi perusahaan itu sendiri.

Pembatasan masalah penulis lakukan agar permasalahan tidak terlalu meluas dari yang sudah ditentukan sesuai dengan masalah yang terkait yaitu: "Pengaruh Kompensasi Dan Lingkungan Kerja Terhadap Kinerja Pegawai

1. Kompensasi adalah semua pendapatan yang berbentuk uang, barang langsung atau tidak langsung yang 
diterima Pegawai sebagai imbalan atas jasa yang diberikan kepada perusahaan

2. Lingkungan kerja adalah segala sesuatu yang berada di sekitar tempat kerja Pegawai, baik yang bersifat fisik maupun non-fisik yang dapat mendukung kinerja seorang Pegawai

3. Kinerja dalam penelitian ini adalah suatu hasil kerja yang dicapai seseorang dalam melaksanakan tugastugas yang dibebankan kepadanya atas kecakapan dan kesungguhan serta waktu yang telah ditentukan.

4. Penelitian dilakukan di Kelurahan Pondok Benda Pamulang yang beralamat di Jalan Raya Siliwangi, No. 02, Pamulang, Benda Baru, Kota Tangerang Selatan, Banten 15417

5. Penelitian ini dilakukan selama 3 (bulan) yaitu bulan November 2020 sampai dengan Februari 2020

\section{TINJAUAN PUSTAKA}

\section{A. Manajemen Sumber Daya Manusia}

\section{Pengertian Manajemen}

"Manajemen berasal dari kata untuk mengelola, yang berarti mengelola, mengelola, mengelola, melaksanakan, dan mengendalikan. Manajemen adalah ilmu dan seni yang mengatur proses pemanfaatan sumber daya manusia dan sumber lain secara efektif dan efisien untuk mencapai tujuan tertentu" (Ardana, 2012:4).

Menurut Kasmir, "manajemen mengelola atau mengelola suatu kegiatan. Dalam arti sempit dikatakan bahwa manajemen mengelola perusahaan untuk mencapai tujuan melalui orang lain. Yang diatur dan dikelola adalah aset atau aset perusahaan, baik properti manusia, peralatan mesin, proses dan prosedur kerja. Aset ini perlu dikelola dengan baik, terus menerus dan berkesinambungan, jika Anda ingin menghasilkan hasil yang optimal seperti yang diharapkan" (Kasmir, 2016:10).

Menurut Lee dalam Swastha dan Sukotjo (2010:82) manajemen adalah ilmu dan seni merencanakan, mengorganisasi, mengarahkan, mengkoordinasikan serta mengawasi tenaga manusia dengan bantuan alatalat unntuk meencapai tuujuan yaang tellah dittetapkan. Darri defiinisi maanajemen tersebut dapat diambil suatu kesimpulan bahwa manajemen mempunyai lima fungsi, yaitu (proses perencanaan, proses pengorganisasian, pengarahan, pengkoordinasian dan pengawasan.

Kelima macam fungsi manajemen ini sangat penting di dalam menjalankan semua kegiatan. Semua ini dimaksudkan agar kegiatan apapun yang dilakukan dapat berjalan baik, sehiingga tuujuan yaang teelah diteetapkan dappat teercapai. Setiiap kegiiatan yaang dilakukan oleh seseorang atau sebuah lembaga tentu memiliki tujuan dan untuk mecapai tujuan perlu adanya perencanaan yang menggambarkan 1) Apa, 2) Bagaimana, 3) Mengapa dan 4) Kapan akan dilakukan (Swastha dan Sukotjo, 2010:82).

\section{Pengertian Sumber Daya Manusia}

Mengelola sumber daya manusia harus dilakukan secara benar sesuai dengan kaidah-kaidah kmanusiaan atau kodratnya. Jika di zaman dahulu manusia atau karyawan dianggap sebagai mesin yang dapat dilakukan dengan semena-mena demi mencapai tujuan perusahaan. Manusia dianggap sebagai budak yang dapat diperintah semaunya. Namun saat ini sesuai dengan perkembangannya, manusia semakin diperhatikan bahkan sekarang sudah berubah menjadi asset yang paling penting untuk diperhatikan (Kasmir, 2016:5). 
Salah satu sumber organisasi yang mempunyai peranan penting dalam mencapai objektifnya adalah sumber manusia. Oleh karena pentingnya peran manusia dalam kompetisi baik jangka pendek maupun jangka panjang dalam agenda bisnis, suatu organisasi harus memiliki nilai lebih dibandingkan dengan organisasi lainnya. Organisasi yang berhasil dalam mempengaruhi pasar jika dapat menarik perhatian atas kelebihan yang dimiliki dalam berbagai hal dibandingkan dengan organisasi lain (Bangun, 2012:4).

Sutrisno (2016:3) mengatakan bahwa summber daaya maanusia meruupakan saatu-satunya sumber daya yang memiliki akal perasaan, keinginan, keterampilan, pengetahuan, dorongan, daya dan karya (rasio, rasa dan karsa). Semua potensi sumber daya manusia tersebut berpengaruh terhadap upaya organisasi dalam mencapai suatu tujuan.

\section{Pengertian Manajemen Sumber Daya Manusia}

Manajemen Sumber Daya Manusia adalah proses pengelolaan manusia, melalui perencanaan, rekrutmen, seleksi, pelatihan, pengembangan, pemberian kompensasi, karier, keselamatan dan kesehatan serta menjaga hubungan industrial sampai pemutusan hubungan kerja guna mencapai tujuan perusahaan dan peningkatan kesejahteraan stakeholder. Pengertian manajemen sumber daya manusia dari beberapa ahli MSDM: Noe menyebutkan Human Resources Management refers to Policies, practices and systems that influenza employees' behavior, attitudes, and performance (manajemen sumber daya manusia merupakan bagaiman mempengaruhi perilaku, sikap dan kinerja melalui kebijakan dan sistem yang dimiliki oleh perusahaan. Menurut Dessler
Human Resources Management is the process of acquiring, training, appraising and compensating employees, and attending their labor relations, health and safety, and fairness concern (manajemen sumber daya manusia merupakan proses mengendalikan latihan penilaian pekerja, pampasan, kesihatan dan keselamatan pekerjaan dengan adil kepada fungsi MSDM.

Pengertian manajemeen summber daya manuusia addalah suatu kegiatan yang meliputi proses perencanaan, proses pengorganisasian, penyusunan personalia, penggerakan dan pengawasan terhadap fungsi-fungsi operasionalnya untuk mencapai tujuan perusahaan (Bangun, 2012:5).

Berdasarkan pengertian di atas maka dapat disimpulkan pengertian Mannajemen Summber Daaya Mannusia addalah segalah kegiatan dengan menggerakan summber dayya manuusia yang ada untuk mencapai tujuan perusahaan.

\section{A. Kompensasi}

Pemberian kompensasi merupakan salah satu pelaksanaan fungsi SDM yang berhubungan dengan semua jenis pemberian penghargaan individual sebagai pertukaran dalam melakukan tugas keorganisasian.

1. Pengertian kompensasi

Suatu cara departemen
personalia dalam usaha untuk
meningkatkan motivasi kerja
Pegawai adalah melalui pemberian
kompensasi. 4 Kompensasi
merupakan segala sesuatu yang
diterima para Pegawai sebagai balas
jasa untuk kerja mereka. Maksud
dari tujuan pemberian kompensasi
ini yaitu untuk membantu Pegawai
memenuhi kebutuhan diluar
kebutuhan rasa adil, serta
meningkatkan motivasi kerja
Pegawai dalam menyelesaikan


tugas-tugas yang menjadi tanggung jawabnya. Untuk lebih jelasnya, definisi kompensasi menurut beberapa para ahli antara lain sebagai berikut:

Menurut Veith Rivai (2013:357) mengemukakan bahwa: "Kompensasi merupakan sesuatu yang diterima Pegawai sebagai pengganti kontribusi jasa mereka pada perusahaan".

Menurut Sedarmayanti (2011:239) menyatakan bahwa kompensasi adalah "segala sesuatu yang di terima oleh Pegawai sebagai balas jasa kerja mereka".

"Kompensasi merupakan sesuatu yang dipertimbangkan sebagai sesuatu yang sebanding. Dalam kePegawaian, hadiah yang bersifat uang merupakan kompensasi yang diberikan kepada Pegawai sebagai penghargaan dari pelayanan mereka".

Menurut A. A. Anwar Prabu Mangkunegara (2013:83) bahwa : "Kompensasi merupakan sesuatu yang di pertimbangkan sebagai suatu yang sebanding”.

Berdasarkan pengertianpengertian di atas dapat disimpulkan bahwa kompensasi adalah pendapatan yang diterima Pegawai sebagai balas jasa atas kontribusinya terhadap pencapaian tujuan perusahaan. Kompensasi digunakan Pegawai dalam pemenuhan kebutuhan hidupnya, sedangkan dengan kompensasi yang diberikan, perusahaan berharap Pegawai dapat meningkatkan kinerjanya dengan lebih baik serta tercapainya kepuasan kerja Pegawai. Effendy (2013:13).

2. Tujuan Manajemen Kompensasi Veithzal Rivai (2013:359), menjelaskan tujuan manajemen kompensasi sebagai berikut: $\begin{array}{rcc}\begin{array}{r}\text { Secara } \\ \text { manajemen }\end{array} & \begin{array}{c}\text { umum } \\ \text { kompensasi }\end{array} & \begin{array}{c}\text { tujuan } \\ \text { adalah }\end{array}\end{array}$ untuk membantu perusahaan mencapai tujuan keberhasilan strategi perusahaan dan menjamin terciptanya keadilan internal dan eksternal. Keadilan eksternal menjamin bahwa pekerjaanpekerjaan akan dikompensasikan secara adil dengan membandingkan pekerjaan yang sama di pasar kerja. Tujuan menejemen kompensasi, meliputi:

a. Memperoleh SDM yang Berkualitas

Kompensasi yang cukup tinggi sangat dibutuhkan untuk memberi daya tarik kepada para pelamar. Tingkat pembayaran harus responsif terhadap penawaran dan permintaan pasar tenaga kerja karena para pengusaha berkompetisi untuk mendapatkan Pegawai yang diharapkan.

b. Mempertahankan Pegawai yang Ada

Para Pegawai dapat keluar jika besaran kompensasi tidak kompetitif dan akibatnya akan menimbulkan perputaran Pegawai yang semakin tinggi.

\section{B. Lingkungan Kerja}

1. Definisi Lingkungan Kerja

Segala macam dan bentuk aktivitas sebuah organisasi tidak akan terlepas dari lingkungan dimana aktivitas itu dijalankan. Baik itu organisasi yang bersifat profit oriented seperti perusahaan maupun yang bersifat nirlaba seperti instansi pemerintahan. Lingkungan kerja menjadi komponen utama dimana pertama kali kontak dengan dunia kerja dilakukan oleh seorang Pegawai. Kenyamanan dalam bekerja seorang Pegawai ditentukan oleh lingkungan kerja di sekitarnya. 
Semakin baik dan kondusif lingkungan kerja pegawai, kenyamanan kerja yang didapatkan pun akan semakin besar.

Sedarmayati

mendefinisikan lingkungan kerja adalah sebagai keseluruhan alat perkakas dan bahan yang dihadapi, lingkungan sekitarnya di mana seseorang bekerja, metode kerjanya, serta pengaturan kerjanya baik sebagai perseorangan maupun sebagai kelompok. Lingkungan kerja adalah sesuatu yang ada disekitar para pekerja dan yang mempengaruhi dirinya dalam menjalankan tugas- tugas yang dibebankan (Nitisemito, 1992).

Sedangkan Schultz \& Schultz (2006) memberikan pengertian lingkungan kerja yaitu suatu kondisi yang berkaitan dengan ciri-ciri tempat bekerja terhadap perilaku dan sikap pegawai dimana hal tersebut berhubungan dengan terjadinya perubahan-perubahan psikologis karena hal-hal yang dialami dalam pekerjaannya atau dalam keadaan tertentu yang harus terus diperhatikan oleh organisasi yang mencakup kebosanan kerja, pekerjaan yang monoton dan kelelahan.

Simpulan dari beberapa definisi menurut ahli yang telah disebutkan di atas, lingkungan kerja adalah segala sesuatu yang berada di sekitar tempat kerja pegawai, baik yang bersifat fisik maupun non- fisik yang dapat mendukung kinerja seorang pegawai. Lingkungan kerja menjadi bagian tak terpisahkan dalam aktivitas kerja seorang pegawai, baik berupa lingkungan kerja fisik maupun lingkungan kerja non-fisik. Tempat kerja dimana seorang mendedikasikan sepenuh tenaga dan pikirannya untuk menghasilkan sesuatu baik secara langsung maupun tidak langsung akan berdampak pada proses kerjanya. Ruang kerja yang bersih, nyaman, dan kondusif diharapkan akan mendukung kinerja seorang pegawai.

Selain lingkungan kerja fisik, lingkungan kerja non-fisik yang bisa berupa hubungan sosial dengan rekan kerja dan atasan. Hubungan sosial yang terjalin dengan sesama pegawai maupun atasan memiliki pengaruh terhadap kenyamanan kerja seorang pegawai yang pada akhirnya akan berdampak pada kedisiplinan dirinya.

2. Faktor yang Mempengaruhi Lingkungan Kerja

Faktor-faktor lingkungan kerja yang diuraikan oleh Nitisemito (1992:184) yang dapat mempengaruhi terbentuknya suatu kondisi lingkungan kerja dikaitkan dengan kemampuan Pegawai, diantaranya:

a. Warna. Merupakan faktor yang penting untuk memperbesar efisiensi kerja para pegawai. Khususnya warna akan mempengaruhi keadaan jiwa mereka. Dengan memakai warna yang tepat pada dinding ruangan dan alat-alat lainnya, kegembiraan dan ketenangan bekerja para pegawai akan terpelihara.

b. Kebersihan Lingkungan Kerja. Secara tidak langsung dapat mempengaruhi seseorang dalam bekerja, karena apabila lingkungan kerja bersih maka Pegawai akan merasa nyaman dalam melakukan pekerjaannya.

c. Penerangan. Dalam hal ini bukan terbatas pada penerangan listrik saja, tetapi juga penerangan sinar matahari. Dalam melaksanakan tugas Pegawai membutuhkan penerangan yang cukup, apabila 
pekerjaan yang dilakukan tersebut menuntut ketelitian.

d. Pertukaran udara yang cukup. Akan meningkatkan kesegaran fisik para Pegawai, karena apabila ventilasinya cukup maka kesehatan para Pegawai akan terjamin. Selain ventilasi, konstruksi gedung dapat berpengaruh pula pada pertukaran udara.

e. Jaminan terhadap keamanan menimbulkan ketenangan.

Keamanan akan keselamatan diri sendiri sering ditafsirkan terbatas pada keselamatan kerja, padahal lebih luas dari itu termasuk disini keamanan milik pribadi Pegawai dan juga konstruksi gedung tempat mereka bekerja..

f. Kebisingan. Merupakan suatu gangguan terhadap seseorang karena adanya kebisingan, maka konsentrasi dalam bekerja akan terganggu. Dengan terganggunya konsentrasi ini maka pekerjaan yang dilakukan akan banyak menimbulkan kesalahan atau kerusakan..

g. Tata ruang. Merupakan penataan yang ada di dalam ruang kerja yang biasa mempengaruhi kenyamanan Pegawai dalam bekerja.

\section{Indikator Lingkungan Kerja}

Indikator lingkungan kerja yang dikemukakan oleh Nitisemito (2012:159) yaitu sebagai berikut:

\section{a. Suasana Kerja}

Suasana kerja adalah kondisi yang ada disekitar Pegawai yang sedang melakukan pekerjaan yang dapat mempengaruhi pelaksanaan pekerjaan itu sendiri. Suasana kerja ini akan meliputi tempat kerja, fasilitas dan alat bantu pekerjaan, kebersihan, pencahayaan, ketenangan termasuk juga hubungan kerja antara orangorang yang ada ditempat tersebut (Saydam, 1996:381)

b. Hubungan dengan rekan kerja

Hubungan dengan rekan kerja yaitu hubungan dengan rekan kerja harmonis dan tanpa ada saling intrik diantara sesama rekan sekerja. Salah satu faktor yang dapat mempengaruhi Pegawai tetap tinggal dalam satu organisasi adalah adanya hubungan yang harmonis diantara rekan kerja.

c. Tersedianya fasilitas kerja

Hal ini dimaksudkan bahwa peralatan yang digunakan untuk mendukung kelancaran kerja lengkap/mutakhir. Tersedianya fasilitas kerja yang lengkap, walaupun tidak baru merupakan salah satu penunjang proses dalam bekerja.

\section{Kinerja Pegawai}

\section{Pengertian Kinerja}

Kinerja merupakan suatu fungsi dari motivasi dan kemampuan untuk menyelesaikan tugas atau pekerjaan, seseorang sepatutnya memiliki derajat kesediaan dan tingkat kemampuan tertentu. Kinerja merupakan perilaku nyata yang ditampilkan setiap orang sebagai prestasi kerja yang dihasilkan oleh Pegawai sesuai dengan perannya dalaam instansi. Kinerja Pegawai merupakan suatu hal yang sangat penting dalam upaya instansi untuk mencapai tujuan. Instansi umumnya mendasarkan perencanaan tujuan yang hendak dicapai di masa depan dengan perilaku yang diharapkan 
dari keseluruhan personel dalam mewujudkan tujuan tersebut.

Tujuan utama penilaian kinerja Pegawai adalah untuk memotivasikan Pegawai dalam mencapai sasaran operasi dan dalam memenuhi standar perilaku yang telah ditetapkan sebelumnya. Berikut ini adalah beberapa pengertian kinerja menurut para ahli:

Menurut Malayu S. P. Hasibuan (2010: 94), menjelaskan bahwa "Kinerja merupakan hasil kerja yang dicapai seseorang dalam melaksanakan tugas-tugas yang dibebankan kepadanya didasarkan atas kecakapan, pengalaman, kesungguhan serta waktu".

Dari beberapa pengertian diatas, dapat disimpulkan bahwa kinerja Pegawai adalah kemampuan mencapai persyaratan-persyaratan pekerjaan, dimana suatu target kerja dapat diselesaikan pada waktu yang tepat atau tidak melalui batas waktu yang disediakan sehingga tujuannya akan sesuai dengan moral maupun etika perusahaan.

\section{Jenis - jenis Kinerja}

Jenis kinerja terdiri atas tiga bagian, antara lain:

\section{a. Kinerja Strategik}

Kinerja suatu perusahaan dievaluasi atas ketepatan perusahaan dalam memilih lingkungan dan kemampuan adaptasi perusahaan bersangkutan atas lingkungan hidupnya dimana dia beroperasi.

b. Kinerja Administratif

$$
\text { Kinerja administratif }
$$
berkaitan dangan kinerja administratif perusahaan, termasuk di dalamnya tentang struktur administrasi yang mangatur hubungan otoritas dan tanggung jawab dari orang- orang yang menduduki jabatan atau bekerja pada unit-unit kerja yang terdapat dalam organisasi.

c. Kinerja Operasional

Kinerja ini berkaitan dengan efektivitas penggunaan setiap sumber daya yang digunakan perusahaan yang efisien, efektif dan produktif, penciptaan motivasi dan dengan pencapaian kepuasan kerja Pegawai serta kinerja Pegawai yang tinggi akan mampu menjadi satu pilar penahan gejolak kehidupan dari luar perusahaan yang memberi tekanan-tekanan baik secara psikologis maupun berdampak financial bagi perusahaan.

\section{B. Hipotesis Penelitian}

Menurut rangka kerja di atas selaras dengan objektif kajian untuk menjawab soalan penyelidikan, hipotesis yang diuji adalah seperti berikut:

1. $\mathrm{H}_{\mathrm{o}}$ : tidak memiliki pengaruh secara parsial (satu per satu) antara variabel gaya kepemimpinan terhadap kepuasan kerja.

$\mathrm{H}_{\mathrm{a}}$ : memiliki pengaruh secara parsial (satu per satu) antara variabel antara gaya kepemimpinan terhadap kepuasan kerja karyawan.

\section{METODDE PEENELITIAN}

\section{Tempat Penelitian}

Penelitian dilakukan di

Kelurahan Pondok Benda yang beralamat di Jalan Raya Siliwangi,. 02, Pamulang, Benda Baru, Kota Tangerang Selatan, Banten 15417.

\section{Waktu Penelitian}

Penelitian ini dilakukan selama 3 (bulan) yaitu bulan Desember 2018 sampai dengan Februari 2019. Langkahlangkah yang penulis ambil dalam mengambil data pada penelitian ini di lakukan secara bertahap mulai dari 
izin kepada Lurah untuk melakukan penelitian dan meminta data dengan cara wawancara kepada perwakilan dari perusahaan untuk mengetahui bagaimana cara yang baik dalam menyebarkan kuisioner yang ada pada perusahaan.

\section{Sifat Penelitian}

Metode Deskriptif menurut Sugiyono (2012:21) adalah metode yang digunakan untuk menggambarkan atau menganalisa suatu hasil penelitian tetapi tidak digunakan untuk membuat kesimpulan yang lebih luas, sedangkan menurut Mohamad Nasir (2015:65) adalah suatu metode untuk meneliti status kelompok manusia. Suatu objek serta kondisi dan sistem pemikiran pada masa sekarang.

Metode Kuantitatif, dilakukan melalui pendekatan korelasional digunakan untuk proses pengujian atas hipotesis penelitian yang di ajukan, yaitu sejauh mana variasi pada suatu faktor yang berkaitan dengan variasi faktor lainnya.

\section{A. Populasi dan Sampel}

\section{Populasi}

Menurut Sugiyono (2011:80)

Populasi adalah wilayah generalisasi yang terdiri atas obyek atau subyek yang mempunyai kualitas dan karakteristik tertentu yang ditetapkan oleh peneliti untuk dipelajari dan kemudian ditarik kesimpulanya. adapun populasi dalam penelitian ini adalah seluruh Pegawai Kelurahan Pondok Benda Pamulang sebanyak 70 orang.

\section{Sampel}

Sampel adalah bagian terkecil dari suatu populasi yang akan diteliti. Sampel tersebut sebagai perwakilan, harus mempunyai sifatsifat atau ciri-ciri yang terdapat pada populasi. Teknik pengambilan data ini dilakukan dengan cara pengambilan obyek dari sampel yang dinamakan sampling/responden. Menurut Sugiyono (2011:81), menyatakan bahwa "Sampel adalah bagian dari jumlah atau karakteristik yang dimiliki oleh populasi tersebut".

Menurut Arikunto (2012:104), jika jumlah populasinya kurang dari 100 maka jumlah sampelnya diambil secara keseluruhan, tetapi jika populasinya lebih besar dari 100 orang, maka bisa diambil 10-15\% atau 20-25\% dari jumlah populasinya.

Dalam penelitian ini, oleh karena populasinya tidak lebih besar dari 100 orang responden. Dengan demikian Sampling Jenuh adalah teknik penentuan sampel yang digunakan dalam penelitian ini. Maka penulis menggunakan $100 \%$ jumlah populasi yang ada pada Kelurahan Pondok Benda Pamulang yaitu sebanyak 70 orang responden.

Teknik pengumpulan data menggunakan temubual dan pemerhatian dan soal selidik. Sampel yang digunakan sebagai objek kajian ialah 70 pegawai.

\section{HASIIL DDAN PEMMBAHASAN}

\section{A. Gambaran Umum}

Metode analisis deskriptif adalah cara merumuskan dan menafsirkan data yang ada sehingga memberikan gambaran yang jelas melalui pengumpulan, penyusunan, penganalisisan data, sehingga dapat diketahui gambaran umum dari objek yang diteliti. Sugiyono (2011:29). Data primer dalam penelitian ini adalah informasi dari responden dan pernyataanpernyataan untuk mendapatkan informasi yang dibutuhkan dalam menganalisis masalah penelitian yang dirumuskan.

Instrumen yang digunakan 
dalam penelitian ini adalah daftar pertanyaan (kuesioner). Jumlah pertanyaan seluruhnya adalah 36 butir pertanyaan yakni 12 butir pertanyaan untuk variabel Kompensasi (X1), 12 butir pertanyaan untuk variabel Lingkungan Kerja (X2) dan 12 butir pertanyaan untuk variabel Kinerja Pegawai (Y).

Analisis deskriptif pada penelitian ini diperoleh dari penyebaran kuesioner kepada 70 orang responden Pegawai Kelurahan Pondok BendaPamulang. Kuesioner berisikan deskripsi responden dan jawaban atas pertanyaan yang diberikan. Karakteristik responden dalam penelitian ini adalah berdasarkan jenis kelamin, usia, pendidikan, dan lama bekerja.

a. Analisis Deskriptif Responden Berdasarkan Jenis Kelamin

Tabel 4.1

Karakteristik Responden Berdasarkan Jenis Kelamin

\begin{tabular}{|l|l|l|}
\hline $\begin{array}{l}\text { Jenis } \\
\text { Kelami } \\
\text { n }\end{array}$ & $\begin{array}{l}\text { Jumlah } \\
\text { Respon } \\
\text { den (f) }\end{array}$ & $\begin{array}{l}\text { Persent } \\
\text { ase (\%) }\end{array}$ \\
\hline $\begin{array}{l}\text { Laki- } \\
\text { laki }\end{array}$ & 41 & 58.57 \\
\hline $\begin{array}{l}\text { Peremp } \\
\text { uan }\end{array}$ & 29 & 41.43 \\
\hline Jumlah & $\mathbf{7 0}$ & $\mathbf{1 0 0}$ \\
\hline
\end{tabular}

Sumber: Hasil Penelitian, 2020 (Data Diolah)

Pada Tabel 4.1 terlihat bahwa karakteristik responden berdasarkan jenis kelamin adalah 41 orang responden $(58,57 \%)$ berjenis kelamin lakilaki dan 29 orang responden $(41,4 \%)$ berjenis kelamin perempuan. Hal ini menunjukkan bahwa jumlah Pegawai laki-laki lebih dominan dibandingkan dengan Pegawai perempuan dengan tingkat perbedaan jumlah yang tidak terlalu besar, agar Pegawai laki-laki dan Pegawai perempuan dapat saling melengkapi dalam menyelesaikan pekerjaan. Pegawai laki-laki cenderung mampu menghadapi beban kerja yang lebih besar dibandingkan dengan Pegawai perempuan, sedangkan Pegawai perempuan cenderung lebih rapi, sabar dan teliti dalam menyelesaikan pekerjaan dibandingkan dengan Pegawai laki-laki, oleh karena itu perbedaan jumlah Pegawai lakilaki dan perempuan yang tidak terlalu besar membuat Pegawai Kelurahan Pondok BendaPamulang dapat saling mendukung dan saling melengkapi dalam menyelesaikan pekerjaan.

b. Analisis Deskriptif Responden Berdasarkan Umur

c. Pengaruh Kompensasi terhadap Kinerja Pegawai

Nilai $t_{\text {hitung }}>\mathrm{t}_{\text {tabel }}$ menunjukkan nilai $4.557>1.996$ dengan signifikansi $0.000<0.05$ hal ini berarti bahwa pengaruh yang terjadi pada kedua variabel ini adalah positif dan signifikan, sehingga hipotesis pertama dapat diterima.

Pemimpin melalui kompensasi yang diterapkannya akan mempempengaruhi kinerja bawahannya. Kompensasi yang sesuai dengan kondisi dan keadaan akan menciptakan iklim kerja yang baik. Dengan terciptanya iklim kerja yang baik maka Pegawai akan bersemangat bekerja. Pemimpin melalui gaya atau caranya memberikan arahan-arahan kepada Pegawai untuk bekerja dengan maksimal sesuai dengan targettarget yang telah ditetapkan oleh 
perusahaan. Selain memberikan arahan, pemimpin juga mampu memberikan dorongan semangat kepada Pegawai untuk bekerja dengan baik. Semakin baik kompensasi yang diterapkan oleh atasan atau pimpinan, maka kinerja Pegawai akan semakin baik pula.

d. Pengaruh Lingkungan kerja terhadap Kinerja Pegawai

Nilai $t_{\text {hitung }}>\mathrm{t}_{\text {tabel }}$ menunjukkan nilai $5.344>1.996$ dengan signifikansi $0.000<0.05$ hal ini berarti bahwa pengaruh yang terjadi pada kedua variabel ini adalah positif dan signifikan, sehingga hipotesis kedua dapat diterima. Lingkungan kerja dapat memberikan pengaruh terhadap kinerja Pegawai. Lingkungan kerja memegang peranan penting dalam menciptakan kinerja pegawai/Pegawai.

Lingkungan kerja yang diberikan perusahaan secara adil dan wajar akan memberikan sebuah dorongan positif kepada Pegawai. Lingkungan kerja akan mempengaruhi kinerja Pegawai secara langsung. Lingkungan kerja yang baik akan mendorong Pegawai bekerja dengan lebih baik, misalnya dengan adanya hadiah bagi Pegawai yang berprestasi atau bonus bagi Pegawai yang bekerja dengan baik maka Pegawai akan selalu memperbaiki diri untuk meningkatkan kualitas kerjanya. Semakin baik, adil dan wajar lingkungan kerja yang diterapkan oleh perusahaan, maka akan meningkatkan kinerja Pegawai.

e. Pengaruh Kompensasi dan Lingkungan Kerja terhadap Kinerja Pegawai

Nilai F $F_{\text {hitung }}>F_{\text {tabel }}$ menunjukkan nilai $52.129>3.13$ dengan signifikansi $0.000<0.05$ hal ini berarti bahwa pengaruh yang terjadi pada kedua variabel ini adalah positif dan signifikan, sehingga hipotesis ketiga dapat diterima

Kompensasi yang tepat akan mampu menciptakan lingkungan kerja yang kondusif bagi Pegawai, hubungan kerja yang baik antara Pegawai dengan atasan, hilangnya kesenjangan sosial antar lini dalam perusahaan, yang akan menciptakan suasana kerja yang nyaman bagi semua pihak temasuk Pegawai. Pegawai akan merasa puas apabila bekerja dengan kondisi atau situasi yang baik sesuai dengan harapan Pegawai tersebut. Setelah kepuasan kerja Pegawai terpenuhi dengan baik, akan berpengaruh terhadap kinerja Pegawai. Kompensasi yang baik akan berpengaruh terhadap meningkatnya kepuasan kerja Pegawai dan selanjutnya setelah Pegawai merasa puas maka kinerja Pegawai tersebut akan meningkat. Pegawai dengan tingkat kepuasan kerja yang tinggi karena kompensasi yang tepat akan berpengaruh positif terhadap kinerja Pegawai yang bersangkutan.

Pemberian lingkungan kerja akan memberikan dorongan kepada Pegawai untuk bekerja secara maksimal, untuk lebih berprestasi dan mencapai target kerja yang telah ditentukan. Ketika Pegawai telah puas dengan lingkungan kerja yang diterimanya baik lingkungan kerja dalam bentuk finansial seperti gaji, bonus atau tunjangan maupun nonfinansial yang berupa hadiah, penghargaan maupun promosi jabatan maka Pegawai akan berusaha meningkatkan kinerjanya. Lingkungan kerja akan berpengaruh terhadap kinerja Pegawai ketika Pegawai merasa puas atau tidak puas dengan lingkungan kerja yang diberikan. Kinerja Pegawai akan maksimal dan 
terus meningkat apabila Pegawai merasa puas dengan lingkungan kerja yang diberikan oleh perusahaan, dan begitu juga sebaliknya kinerja Pegawai akan menurun apabila Pegawai kecewa dengan lingkungan kerja dari perusahaan. Lingkungan kerja yang diberikan secara adil akan membuat Pegawai puas dan pada akhirnya akan berpengaruh terhadap kinerja Pegawai tersebut.

\section{KESIMPULAN DAAN SARAN}

\section{A. Kesimpulan}

Berdasarkan hasil analisis dan pembahasan yang telah dilakukan dalam penelitian ini, maka diambil kesimpulan sebagai berikut:

1. Pengaruh Kompensasi Terhadap

Kinerja PegawaiNilai thitung menunjukkan nilai 4.557 dengan signifikansi 0.00 hal ini berarti bahwa pengaruh kompensasi terhadap kinerja Pegawai adalah positif dan signifikan, sehingga hipotesis kesatu dapat diterima

2. Pengaruh Lingkungan Kerja Terhadap Kinerja Pegawai Nilai $\mathrm{t}_{\text {hitung }}$ menunjukkan nilai 5.344 dengan signifikansi 0.00 hal ini berarti bahwa terdapat pengaruh lingkungan kerja terhadap kinerja Pegawai adalah positif dan signifikan, sehingga hipotesis kedua dapat diterima

3. Kompensasi Dan Lingkungan Kerja Terhadap Kinerja Pegawai Secara serempak berpengaruh signifikan terhadap kinerja Pegawai Kelurahan Pondok BendaPamulang. Berdasarkan nilai $\quad F_{\text {hitung }}$ menunjukkan nilai 52.129 dan signifikansi 0.000 Artinya pengaruh kompensasi dan lingkungan kerja terhadap kinerja Pegawai adalah positif dan signifikan, sehingga hipotesis ketiga dapat diterima.

\section{A. Saran}

1. Berdasarkan hasil kuesioner untuk kompensasi, indikator kepemimpinan partisipatif mempunyai nilai paling rendah, untuk itu Perusahaan perlu meningkatkan peran pemimpin atau manajemen atas untuk meningkatkan kepuasan dan kinerja Pegawai.

2. Berdasarkan hasil kuesioner untuk variabel lingkungan kerja, indikator insentif mempunyai nilai paling rendah, untuk itu insentif harus diberlakukan secara adil dan wajar sesuai dengan beban kerja yang diberikan kepada Pegawai. Selain itu, perlu adanya lingkungan kerja nonfinansial seperti bonus, promosi, tunjangan-tunjangan di luar gaji pokok dan lingkungan kerja nonfinansial lainnya sebagai media untuk meningkatkan kepuasan kerja dan kinerja Pegawai.

3. Berdasarkan hasil kuesioner untuk variabel kinerja, indikator kualitas kerja memiliki nilai paling rendah, untuk itu Perusahaan perlu menciptakan hubungan kerja yang baik dan kondusif, baik antar sesama Pegawai maupun antara Pegawai dengan manajemen di atasnya.

\section{DAFTAR PUSTAKA}

Ghozali, Imam, "Aplikasi Analisis Multivariat Dengan Program SPSS 19”, Badan Penerbit Universitas Dipenogoro, Semarang, 2011.

Hasibuan, Melayu, "Manajemen Sumber Daya Manusia", PT. Bumi Aksara, Jakarta, 2012.

Krisnaldy, K., Pasaribu, V. L. D., \& Senen, S. (2019). Pengaruh Budaya Organisasi, Lingkungan Kerja Dan 
Iklim Organisasi Terhadap Motivasi Pegawai Serta Dampaknya Terhadap Kepuasan Kerja. Jurnal

Semarak, 2(2), 164-183.

Krisnaldy, K., Pasaribu, V. L. D., \& Batubara, A. S. (2020). Analisis Pengaruh Kedisiplinan Terhadap Performa Pegawai Kelurahan Rempoa, Kota Tangerang Selatan. Jurnal Mandiri: Ilmu Pengetahuan, Seni, Dan Teknologi, 4(2), 131-138.

Pasaribu, V. L. D., \& Krisnaldy, K. (2018).

ANALISIS KEPUASAN

JAMA'AH PADA KINERJA DEWAN KEMAKMURAN MASJID AL-HIDAYAH PERIODE TAHUN 2017. KREATIF: Jurnal Ilmiah Prodi Manajemen

Universitas Pamulang, 6(4), 41-51.

Pasaribu, V. L. D., Krisnaldy, K., \& Warasto, H. N. (2020). Pengaruh Gaya Kepemimpinan, Disiplin Kerja Dan Kompensasi Terhadap Kinerja Pegawai (Studi kasus kelurahan Pisangan Ciputat). Jurnal Disrupsi Bisnis: Jurnal Ilmiah Prodi Manajemen, Fakultas Ekonomi, Universitas Pamulang, 3(1).

Pasaribu, V. L. D., \& Yanuarso, B. P. (2021). PENGARUH STRES KERJA DAN DISIPLIN KERJA TERHADAP KINERJA KARYAWAN PADA PT. MULTRITRAN ABADI SRENGSENG JAKARTA BARAT PERIODE 2018. Jurnal Sekretari Universitas Pamulang, 8(1), 60-72.

Rosidah, Ambar Teguh Sulistiyani, "Manajemen Sumber Daya Manusia”, Graha Ilmu, Yogyakarta, 2009.

Sunyoto, Danang, "Sumber Daya Manusia (Praktik Penelitian)", Center For Academic Publishing Service), Yogyakarta, 2012.
Riani, Asri Laksmi, "Manajemen Sumber Daya Manusia, Graha Ilmu, Yogyakarta, 2013..

Hariandja, Marihot Tua Efendi, "Manajemen Sumber Daya Manusia”, Grasindo, Jakarta, 2007.

Sunyoto, Danang, "Sumber Daya Manusia (Praktik Penelitian)", Center For Academic Publishing Service, Yogyakarta, 2012.

Swastha, Bashu, Ibnu Sukotjo, "Pengantar Bisnis”, Liberti, Yogyakarta, 2010

Sutrisno Edi, "Manajemen Sumber Daya Manusia”, Kencana, Jakarta, 2016.

Bangun, Wilson, "Manajemen Sumber Daya Manusia”, Erlangga, Jakarta, 2012.

Kasmir, "Manajemen Sumber Daya Manusia (Teori dan Praktik)”, PT. Raja Grafindo Persada, Jakarta, 2016. 